DOI:http://dx.doi.org/10.18524/1810-4215.2020.33.216436

\title{
SIGNATURES OF EXOCOMET ACTIVITY AROUND STARS AT DIFFERENT EVOLUTIONARY STAGES
}

\author{
Y. Kuznyetsova, Ya. Pavlenko, I. Kulyk, O. Zakhozhay, P. Korsun, \\ S. Borysenko, V. Krushevska, O. Shubina, M. Andreev \\ Main astronomical observatory of NAS of Ukraine, \\ Kyiv, Ukraine,juliana@mao.kiev.ua
}

\begin{abstract}
We discuss the current state of problems associated with the discovery and study of exocomets, i.e objects of extrasolar systems, that are in many aspects similar to the solar system comets. Thus far, more than 4,300 exoplanetary systems have been discovered, but little is known about the populations of subplanetary bodies in these systems, in particular comets. Existing theories of planet formation suggest that populations of small bodies in the planetary systems should be numerous, especially at the early stages of their formation. Currently, most of the stars observed with the confirmed transit exoplanets and candidate stars with exoplanetary systems have been collected in the Kepler and TESS space mission databases. These databases can be used for a search and study of the exocomet transit signatures in extrasolar systems. So far, the number of observed cases of exocomet transits has been small, only about 20 events. Due to the rapid accumulation of data, new researches aimed to identify the specific transit events and study the physical characteristics of small bodies in the extrasolar systems are of great importance.Worth considering is the concept of "falling evaporating bodies", massive enough bodies surrounded by miniatmospheres, which fall on the parent star. The events might produce the variable, short-time red-shifts of some spectral features in their spectra. Alternative evidence of exocomet transits can be obtained by detection of the cometary emissions in $\mathrm{CO}, \mathrm{C}$, and $\mathrm{O}$ lines in the millimeter region of the spectra of debris disks by the ALMA and APEX telescopes. We discuss the known detection methods based on the analysis of the photometric and spectral series of observational data of space missions and groundbased complexes. Some results of experimental studies of the exocometary transit signatures obtained by other authors are presented and discussed.
\end{abstract}

Keywords: extrasolar planetary systems, exocomets.

АНОТАЦІЯ. У даній роботі обговорюється сучасний стан проблем, пов'язаних з відкриттям та дослідженням екзокомет - об'єктів позасонячних систем, багато в чому подібних до комет Сонячної системи. На сьогодні відкрито вже більше 4300 екзопланетних систем, але водночас мало що відомо про популяції субпланетних тіл у цих системах, зокрема комет. Існуючі теорії формування планет передбачають, що популяції малих тіл планетних систем можуть бути багаточисельними, особливо на ранніх стадіях їх формування. Наразі основна кількість спостережень зір із підтвердженими транзитами та ймовірних зір-кандидатів 3 екзопланетними системами накопичена в базах даних космічних місій Kepler та TESS. Ці бази даних можуть використовуватися і для пошуку та вивчення проявів екзокометної активності в позасонячних системах. На сьогодні чисельність спостережених проявів екзокометної активності є дуже незначною, всього близько 20 подій. Але швидке накопичення даних стимулює активні дослідження, направлені на виявлення та вивчення фізичних характеристик малих тіл у позасонячних системах. У нашій роботі представлено основні методи детектування, які грунтуються на аналізі фотометричних та спектральних рядів спостережних даних космічних місій та наземних спостережних комплексів. Наведено та обговорено результати експериментальних досліджень проявів екзокометної активності, отриманих іншими авторами. Наголошується необхідність більш комплексного аналізу наявних проблем. Вартою розгляду $є$ концепція падіння на зорю маломасивних тіл, оточених мініатмосферами, так званих "falling evaporating bodies". $\mathrm{y}$ спектрах це проявляється появою мінливих, часто короткотривалих, змін зі зміщенням у червону ділянку спектра. Іншим ймовірним свідченням кометної активності є випромінювання в лініях $\mathrm{CO}, \mathrm{C}$ та О в міліметровій ділянці спектра, що спостерігалися в уламкових дисках телескопами ALMA та APEX.

Ключові слова: позасонячні планетні системи, екзокомети. 


\section{Introduction}

During recent years, the transit method for the study of extrasolar planetary systems has shown its effectiveness. Using this method, the following lowmass bodies have already been discovered:

- Sub-Earths: the smallest solid body, moon-size Kepler 37b object, which was detected in 2013 [Barclay et al., 2013].

- Disintegrating planets: Ceres-sized objects with short-period orbits ( $\sim 10$ hours), which were detected spectroscopically, but detection is possible by the transit photometric method assumed that objects are surrounded by optically thick material (eg, dust). This fact leads to increasing of depths on the transit light curve of the parent star. Examples of such objects are KIC 12557548b, KOI 3794 [Rappaport et al., 2012], KOI 2700b [Rappaport et al., 2014?], K2-22 [Sanchis-Ojeda et al., 2015].

- Comets in other stellar systems: 6 asymmetric transits in the system KIC 3542116 (F2V) and one in the system KIC 11084727 (F5V) were detected; their transit light curves have an asymmetric appearance and correspond to that, which could be caused by an object having the cometary coma and tail [Rappaport et al., 2018].

\section{Orbital observational complexes}

The majority of observations of stars with confirmed transits and probable candidate stars with exoplanetary systems have been accumulated in the Kepler and TESS space mission databases. Kepler Space Telescope was the first mission planned specifically to discover and study exoplanets resembling terrestrial planets located in a habitable zone. Observations were carried out using $0.95 \mathrm{~m}$ telescope of Schmidt system with a CCD photometer in the spectral range $420-905 \mathrm{~nm}$. During the period from 2009 to 2013, the photometric monitoring of brightness changes of about 170,000 stars within a sky area $\sim 115$ square degrees was performed. The photometric accuracy for calculating the brightness curves is estimated at $0.002 \%$ for a star of 12 magnitude and spectral class $\mathrm{G} 2 \mathrm{~V}$ when integrated for 6.5 hours [Jenkins et al., 2010].

The main task of the TESS (Transiting Exoplanet Survey Satellite) mission is the search for transits by exoplanets across the nearest and brightest stars. The TESS is located in high satellite orbit in 2:1 resonance with the Moon. It maintains the optimal thermal regime and necessary geometric conditions for the approximately similar visibility of selected sky area for the observations. The TESS has four wide-angle cameras, each with a field of view $24^{\circ} \times 24^{\circ}$, which makes it possible to obtain simultaneously an image of the celestial sphere band $24^{\circ} \times 96^{\circ}$ from the ecliptic plane to its pole. A total of $15,000-20,000$ stars are observed in each band for 27 days. The bandwidth of the cameras cuts the spectral region $600-1040 \mathrm{~nm}$. It is expected that the catalog final version will contain the results of monitoring of stars brighter than 13 mag in the camera spectral band, meanwhile a particular attention will be paid to more than 200,000 cool dwarfs of spectral classes F-G-K-M to search for exoplanets with radii between 2.5 and 4.2 of the Earth radius [Stassun et al., 2019].

\section{The difference between the light curves of exoplanets and exocomets}

Ordinary transit profiles of exoplanets are U-shaped. If a planet passes through the host star disk, the light curve has a symmetrical profile with respect to the center of the transit. The asymmetric shape of the photometric transit profile, as it seen in Fig. 1, can be considered as a manifestation of the presence of an object with the dusty tail. Rappaport et al. (2018) investigated a set of 201,250 photometric light curves from the Kepler database. Several transits were found and interpreted as exocometary ones for stars KIC 3542116 (Fig. 1) and KIC 11084727. These transits have a pronounced asymmetric shape with a steeper drop in starlight at the beginning of the transit event and a slower increase in brightness of the star when leaving the shadow. The similar shape and depth of transits are theoretically predicted in the work of Lecavelier des Etangs et al. (1999) for the case when an extended comet-like object surrounded by a dusty atmosphere passes through the star's disk. The depth of the light curve in Fig. 1 is about $0.1 \%$, the duration of the transit is about 1 day. Opposite to planet transits, photometric profiles of exocometary transits reveal a relatively small amplitude and a fairly long duration, an average of 1.5 days. It is worth to note that the transit profile of a disintegrating planet with the long dusty tail and small fragments could also have a similar shape. However, the researchers ruled out this possibility, because in this case there should be periodicity in transit events, meanwhile an exocomet transits are sporadic ones.

Rappaport et al. (2018) calculated the basic parameters of exocomets. They assumed that the asymmetry of the transit profile is associated with the transit of a comet having the dust tail shifted in the direction opposite to the direction of the comet motion. The calculated orbital velocities are within 35.2 


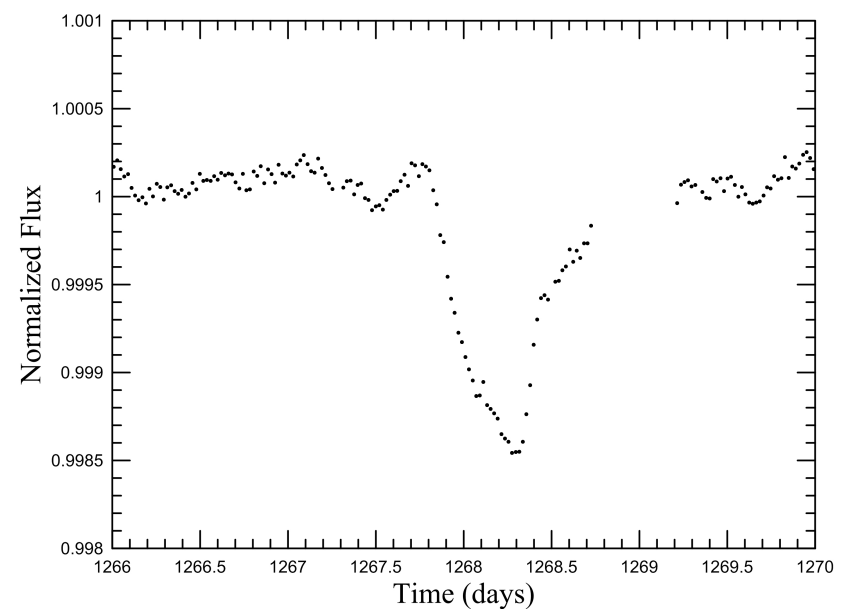

Рис. 1: Asymmetric transit of an exocomet in the system of KIC 3542116 plotted based on the data from MAST archive.

- $89.8 \mathrm{~km} / \mathrm{s}$; tail lengths are within the range from $3.1 \times 10^{5}$ to $5.9 \times 10^{5} \mathrm{~km}$. The estimated mass of the exocomet $M_{c} \geq 10^{17} \mathrm{~g}$, correlates with the mass of Halley's comet, i.e. $2.2 \times 10^{17} \mathrm{~g}$ [Cevolani et al., 1987].

Another interesting case for exocomet investigation provides the star Beta Pictoris ( $\beta$ Pictoris) located at a distance of 63.4 light years from the Earth. Fig. 2 shows the image of the $\beta$ Pictoris system made by HST [Mouillet et al., 1997]. The age of the star is estimated as $8-$ 10 Myrs. Icy bodies similar to those in the Kuiper belt in our Solar System are likely condensed in dust and gas disc around the star. Fortunately, from the Earth we can see the disk from its edge. Strong dust scattering makes the disk quite bright for the observations .

Zieba et al. (2019) analyzed the TESS observation of star $\beta$ Pictoris for the period October 19, 2018 February 1, 2019 and identified several asymmetric transits. These authors estimated the orbital velocity of exocomet to be $19.6 \pm 0.1 \mathrm{~km} / \mathrm{s}$, and the probable length of the tail of order $2 \times 10^{8} \mathrm{~km}$ at a distance from the star of $r=1 \mathrm{AU}$.

\section{Stars and exocomets}

Existing theories of planet formation suggest that populations of small bodies in planetary systems should be large. It is expected that more pronounced signatures of exocometary activity can be detected at the early stages of the stellar evolution, i.e. around the stars of spectral types A - F, surrounded by debris disks of aged from several millions to $0.5 \mathrm{Gyr}$. It is considered that more massive stars may have massive protoplanetary (primordial) disks. In this case larger bulks of secondary material, like disk fragments, will remain around a star and become a source of cometary and asteroid "material" in the system. Such fragments

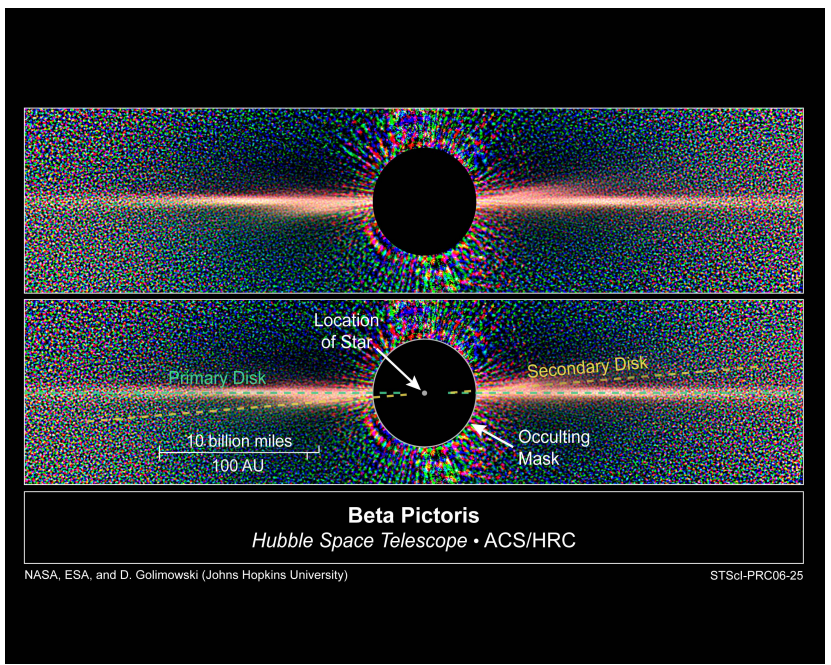

Рис. 2: The disk of $\beta$ Pictoris formed by the multiple belts of debris material with different inclinations. The size of dust disk is much more than $100 \mathrm{AU}$ [Wahhaj et al., 2003; Okamoto et al., 2004; Quillen et al., 2007]. Credits: (C)NASA, ESA, D. Golimowski (Johns Hopkins University), D. Ardila (IPAC), J. Krist (JPL), M. Clampin (GSFC), H. Ford (JHU), and G. Illingworth (UCO/Lick) and the ACS Science Team

can be expected to exhibit CO emissions, as can be seen for HD 181327 [Marino et al., 2016], $\eta$-Corvi [Marino et al., 2017], and Fomalhaut [Matrà et al., 2017]. For these systems, circumstellar CO emissions were recorded by radio observations. It was interpreted in favor of the presence of significant populations of small bodies at large orbital distances.

In general, emissions of $\mathrm{CO}, \mathrm{C}$ and $\mathrm{O}$ lines are observed in debris disks by ALMA and APEX telescopes in the millimeter region of the spectrum. The Table 1 presents the list of the young stars where gas has been detected and which may be of interest for finding exocomets or other low-mass bodies.

As it was noted above, the bulk of the photometric observations of transit phenomena is accumulated in the databases of the space telescopes. During the TESS mission, special attention is paid to the observations of close bright dwarfs having radii in the range $\sim 0.1$ - 4.0 solar radius, in order to detect transits caused by small objects of the Earth's size. Could we expect the evidences of exocometary activity in the systems of these stars? Assuming that the main component of exocomets (like for comets of the Solar system) is the ices of volatile elements, we expect the development of comet-like activity when the object is approaching to the parent star and its surface temperature increases. We calculated the dependence of the equilibrium temperature on the distance from a host star, assuming that the amount of radiation absorbed by the nucleus is equal to the amount of the radiation 
Табл. 1: Stars with debris disks in which gas was detected.

\begin{tabular}{cccc}
\hline Star & Right ascension & Declination & Reference \\
\hline HD 21997 & 033154 & -253651 & Moór et al. 2011 \\
HD 32297 & 050227 & +072740 & Redfield 2007 \\
HD 10908 (eta Crvor, 8 Crv) & 123204 & -161146 & Marino et al. 2017 \\
HD 149630 (sig Her, 35 Her) & 163406 & +422613 & Chen \& Jura 2003 \\
HD 158643 (c Ophor, 51 Oph) & 173125 & -235746 & Thi et al. 2013 \\
HD 181327 & 192259 & -543217 & Marino et al. 2016 \\
\hline
\end{tabular}

emitted. It is shown in Fig 3 together with the sublimation temperatures of pure ices of certain volatile elements $\left(\mathrm{CO}, \mathrm{NH}_{3}, \mathrm{CH}_{3} \mathrm{OH}, \mathrm{H}_{2} \mathrm{O}\right)$, which have been found in the solar system comets [Meech and Svoren, 2004]. These estimates are based on the simple equilibrium model and some parameters derived for the solar system comets, such as the surface albedo and roughness, bolometric emissivity, zero thermal inertia as well as on assumption of rapid rotation of the comet's nucleus [Spencer et al., 1989]. Nevertheless, Fig. 3 shows that in the exoplanet systems similar to our Solar system, we can expect the manifestation of cometary activity due to sublimation of water ice at distances of about $3 \mathrm{AU}$. In the systems of the hosting stars larger than the Sun $(1.4-4.2$ solar radii) the ices of volatile elements, including water ice, are likely to evaporate at distances greater than $20 \mathrm{AU}$. Comet-like activity at close distances is likely to be caused only by the decay and evaporation of the solid component of the comet's nucleus. Around smaller stars $(0.65-0.79$ solar radii), the comet-like activity can occur at closer distances $(\sim 1 \mathrm{AU})$ and only if the cometary nucleus includes a significant part of ice impurities that are more volatile than water ice. Therefore, to search for comet-like activity in the TESS satellite database, it is necessary to select the objects from the list of candidates, which includes the dwarfs of spectral types F0 $\mathrm{K} 5$ with radii in the range of $0.7-2.0$ of the solar radius. Both the relatively small radii of these stars and the effective temperatures in the range of $4000-7500 \mathrm{~K}$ increase the probability to detect a transit phenomenon caused by small objects, including exocomets. Indeed, the volatile small bodies in the systems of such stars may develop the comet-like activity in the interval of distances of $1-20$ astronomical units from the host star.

\section{Conclusions}

Nowadays, the very fact of the existence of comets in the exoplanetary systems is not in doubt. First robust detections, both spectroscopic and photometric, point out likely the abundance of exocomets in extrasolar stellar systems. We expect that similarly

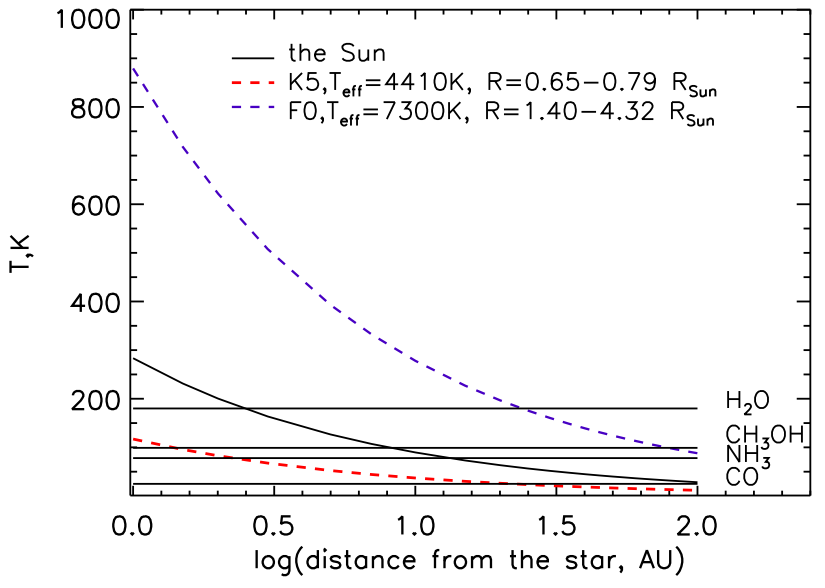

Pис. 3: Equilibrium black-body temperature vs. the distance to a host star. The horizontal lines mark the sublimation temperature of the pure ices of corresponding molecules in vacuum.

to comets in the Solar system, exocomets are bodies of the ages comparable with the age of the planetary system formation. The detection of exocomets can be interpreted as indirect evidence of the existence of exoplanets,as well as the presence of dust in the system might indicate a large number of collisions of small bodies in this system.

According to the modern knowledge, volatile small bodies - remnants of the planet formation - can deliver water and other volatile substances to the planets, which indicate their importance for astrobiology. There is no doubt that the discovery of exocomets by photometric and spectral methods using the groud-based optical observations and space orbital telescopes, provide a better understanding of the evolution of star-planetary systems and the nature of physical processes in the Solar system.

Acknowledgements. This study was funded as part of the routine financing programme for institutes of the National Academy of Sciences of Ukraine. The researches were partially supported by the 1230 program 16.01.2020 № $3 / 20$ of the National Academy of Sciences and grant of the National Research Foundation of Ukraine № 2020.02/228. 


\section{References}

Barclay T., Rowe, J.F., Lissauer J.J., et al.: 2013, Nature, 494, issue 7438, 452.

Cevolani G., Bortolotti G., Hajduk A.: 1987, Nuovo Cimento C Geophysics Space Physics C, 10, 587.

Chen C.H. and Jura M.: 2003, Astrophys. J., 582, issue $1,443$.

Jenkins J.M., Caldwell D.A., Chandrasekaran H. et al.: 2010, Astrophys. J. Lett., 713, issue 2, L120.

Lecavelier Des Etangs A., Vidal-Madjar A., Ferlet R.: 1999, Astron. and Astrophys., 343, 916.

Marino S., Matrà L., Stark C., et al.: 2016, MNRAS, 460, issue 3, 2933.

Marino S., Wyatt M.C., Panić O., et al.: 2017, MNRAS, 465, issue 3, 2595.

Matrà L., MacGregor M.A., Kalas P., et al.: 2017, Astrophys. J., 842, issue 1, id. 9, 15 pp.

Meech K.J., Svoren J.: 2004, Comets II Festou M.C., Keller H.U., and Weaver H.A. (eds.), University of Arizona Press, Tucson, 745 pp., 317.

Moór A., Бbrahám P., Juhász A., et al.: 2011, Astrophys. J. Lett., 740, issue 1, id. L7, 6 pp.

Mouillet D., Lagrange A.-M., Beuzit J.-L., Renaud N.: 1997, A\&A, 324, 1083.
Okamoto Y.K., Kataza H., Honda M., et al.: 2004, Nature, bf 431, issue 7009, 660.

Quillen A.C., Morbidelli A., and Moore A.: 2007, MNRAS, 380, issue 4, 1642.

Rappaport S., Barclay T., DeVore J., et al.: 2014a, Astrophys. J., 784, issue 1, id. 40, 16 pp.

Rappaport S., Levine A., Chiang E., et al.: 2012, Astrophys. J., 752, issue 1, id. 1, 13 pp.

Rappaport S., Vanderburg A., Jacobs T., et al.: 2018, $M N R A S, 474$, issue 2, 1453.

Redfield S.: 2007, Astrophys. J., 656, issue 2, L97.

Sanchis-Ojeda R., Rappaport S., Pallè E., et al.: 2015, Astrophys. J., 812, issue 2, id. 112, 22 pp.

Spencer J.R., Lebofsky L.A., and Sykes M.V.: 1989, Icarus, $\mathbf{7 8}, 337$.

Stassun K.G., Oelkers R.J., Paegert M., et al.: 2019, $A J, \mathbf{1 5 8}$, issue 4, id. 138, 21pp.

Thi W.F., Ménard F., Meeus G., et al.: 2013, Astron. and Astrophys, 557, id. A111, 11 pp.

Wahhaj Z., Koerner D.W. Ressler M.E., et al.: 2003, The Astrophysical Journal, 584, issue 1, L27, 5pp.

Zieba S., Zwintz K., Kenworthy M. A., Kennedy G.M.: 2019, Astron. and Astrophys., 625, id. L13, 7 pp. 